\title{
SUBSTRATE USE AND SELECTION IN SYMPATRIC INTERTIDAL HERMIT CRAB SPECIES
}

\author{
TURRA, A. and DENADAI, M. R. \\ Departamento de Zoologia, Programa de Pós-graduação em Ecologia, IB, Unicamp, \\ Campinas, CEP 13083-970, SP, Brazil \\ Correspondence to: Alexander Turra, Departamento de Zoologia, Programa de Pós-graduação em Ecologia, IB, \\ Unicamp, CEP 13083-97, Campinas, SP, Brazil, e-mail: turra@unicamp.br \\ Received January 30, 2001 - Accepted February 23, 2001 - Distributed February 28, 2002
}

(With 1 figure)

\begin{abstract}
Coexisting hermit crabs may competitively interact for shells and microhabitats, mainly when shell availability is habitat-related. Three species of Clibanarius (C. antillensis, C. sclopetarius, and $C$. vittatus) coexist in the intertidal region of Pernambuco Islet, Araçá Region, São Sebastião Channel, southeastern Brazil. This study evaluated crab preferences for four substrate types used by these species in nature (rocky shore, pebbles, sand, and mud) in allopatric (single species) and sympatric (three species) treatments in simulations of high tide and low tide. The substrate preference of the three hermit crabs did not vary between low and high tide situations. At low tide the crabs either moved into holes in the highly complex rocky substrate or buried themselves in mud. Substrate selection may explain the patterns of substrate use in nature only for C. vittatus. Clibanarius antillensis and C. sclopetarius showed closer similarities in the pattern of substrate selection in the sympatric treatment with the substrate use in nature than in allopatric treatment, indicating a positive influence (dependence) of the presence of one species on the presence of another. Use of sub-optimal substrates, mainly by $C$. antillensis, may be caused by other factors such as its low desiccation tolerances. If competition for space takes place among these species, it would be more intense between $C$. sclopetarius and $C$. vittatus given their higher overlap in substrate preference than between them and $C$. antillensis.
\end{abstract}

Key words: resource partitioning, coexistence, substrate use, substrate selection, hermit crabs, Clibanarius, Diogenidae, Anomura, intertidal, southeastern Brazil.

\section{RESUMO}

\section{Uso e seleção de substratos em espécies simpátricas de ermitões}

Espécies de ermitões coexistentes podem realizar interações competitivas por conchas e microambientes, principalmente quando a disponibilidade de conchas está relacionada aos microambientes. Três espécies de ermitões do gênero Clibanarius ( $C$. antillensis, $C$. sclopetarius e $C$. vittatus) coexistem na região entremarés da Ilha de Pernambuco, região do Araçá, Canal de São Sebastião, Sudeste brasileiro. Este estudo avaliou a preferência dos ermitões por quatro tipos de substrato (costão, seixos, areia e lodo) utilizados por eles na natureza em tratamentos alopátricos (uma espécie) e simpátricos (três espécies) em situações simuladas de marés alta e baixa. A preferência por tipos de substrato não variou entre as simulações de marés alta e baixa. Na maré baixa, os ermitões deslocaram-se para buracos e fendas ou enterraram-se no lodo. A seleção de substratos pode explicar o padrão de uso de substratos na natureza apenas para $C$. vittatus. Clibanarius antillensis e $C$. sclopetarius apresentaram maiores similaridades na seleção de substratos no tratamento simpátrico e no uso na natureza que no tratamento alopátrico, indicando influência positiva (dependência) da presença de uma espécie em função da outra. $\mathrm{O}$ uso de substratos subótimos no campo, principalmente por $C$. antillensis, pode ter sido causado por outros fatores, como suas baixas tolerâncias à dessecação. Se houver competição por substratos 
entre as três espécies, ela será mais intensa entre $C$. sclopetarius e $C$. vittatus, dada a maior sobreposição na preferência por substratos entre essas espécies que entre elas e $C$. antillensis.

Palavras-chave: partilha de recursos, coexistência, uso de substratos, seleção de substratos, ermitões, Clibanarius, Diogenidae, Anomura, entremarés, Sudeste brasileiro.

\section{INTRODUCTION}

Hermit crabs are typical marine organisms but many species have physiological and behavioral adaptations for living in terrestrial and semi-terrestrial habitats. In fact, hermit crabs are a successful crustacean group in the intertidal region (Reese, 1969). Their pattern of distribution has been described geographically (Forest \& Saint Laurent, $1967)$ and was recently revised for the Brazilian coast by Melo (1999). In general, studies of regional patterns of distribution have focused on comparing the structure of hermit crab assemblages on a scale of kilometers (Bach et al., 1976; Scully, 1979; Barnes, 1997; Leite et al., 1998). Smallscale studies have described vertical distribution along the intertidal region (Reese, 1969; Kellogg, 1977; Young, 1978; Taylor, 1981; Imazu \& Asakura, 1994; Barnes, 1997; Turra et al., 2000) and the differential use of microhabitats (Kellogg, 1977; Lowery \& Nelson, 1988; Rittschof et al., 1995; Turra et al., 2000). The dispersion patterns of hermit crab populations are seldom described (Turra \& Leite, 2000; Turra et al., 2000) while their clustering behavior is more frequently studied (SnyderConn, 1981; Gherardi \& Vannini, 1989, 1992, 1993; Turra \& Leite, 2000; Turra et al., 2000).

The coexistence of hermit crab species may expose them to competitive interactions (Bach et al., 1976; Gherardi, 1990). Differential use of microhabitats (Mitchell, 1975; Kellogg, 1977; Gherardi, 1990; Rittschof et al., 1995), as well as shells (Vance, 1972; Bach et al., 1976; Gherardi \& Nardone, 1997), is thought to be responsible for enabling species coexistence. Some studies have focused on the selection of microhabitats, emphasizing resource partitioning among coexisting species by verifying preferred or sub-optimal substrates in the field (Mitchell, 1975; Gherardi, 1990).

Turra et al. (2000) found that the coexisting hermit crab species at the Pernambuco Islet (Araçá region, São Sebastião Channel, southeastern Brazil) used eleven kinds of microhabitats, which may be grouped into four substrate type categories: highly complex rocky shore, pebbles, coarse sand, and mud. The present study tests preferences for substrate types by the three coexisting Clibanarius species in this area (C. antillensis, $C$. sclopetarius, and $C$. vittatus) through comparisons among species and with field data on substrate use (Turra et al., 2000). Substrate selection was tested in low and high tide simulations and in two treatments: allopatric (single species) and sympatric (the three species together). Results were used to test if the patterns of substrate use in nature may be explained by substrate preferences or by resource partitioning among these coexisting hermit crabs species.

\section{MATERIAL AND METHODS}

The substrate preference was evaluated for three sympatric hermit crab populations of the genus Clibanarius [C. antillensis Stimpson 1859, C. sclopetarius (Herbst 1796), and C. vittatus (Bosc 1802)] at the Pernambuco Islet (2349'S, $\left.45^{\circ} 24^{\prime} \mathrm{W}\right)$. The substrates used in the selection experiments were based on previous studies on microhabitat utilization by these hermit crab species in the same area (Turra et al., 2000).

A plastic pool with $2.431 \mathrm{~m}^{2}$ base area $(1.87 \times$ $1.30 \mathrm{~m}$ ) was divided into four quadrants simulating four substrate types (highly complex rocky shore, pebbles, sand, and mud) used by the hermit crabs in the intertidal region of Pernambuco Islet. Allopatric (single species) and sympatric (three species) treatments were conducted. Three trials were carried out for each species in the allopatric treatments, using twenty individuals per trial. In the sympatric treatment, fifteen individuals of each species (totalling 45 individuals in each of the three trials) were used. At the beginning of each trial, the individuals were placed at the center of the pool. After five hours (following Mitchell, 1975) with running 
seawater $\left(34-35 \%, 25^{\circ} \mathrm{C}\right)$, the selected substrates were inspected in the submerged condition, i.e., simulating high tide. Later, the pools were slightly emptied ( $30 \mathrm{~min})$ and the selected substrates were examined again in a low tide simulation. The behavior of the hermit crabs was observed during this process.

The frequencies of the individuals using each type of substrate in each of the three trials were combined for each species in each treatment. These combined frequencies were compared among species within and between treatments and between low and high tide conditions using the log-likelihood G-test (Zar, 1996). This test was also employed to contrast the patterns of substrate selection in the experiments with those used in the field previously recorded (Turra et al., 2000).

\section{RESULTS}

The patterns of substrate selection for the three species were similar in the allopatric and sympatric treatments between the high and low tide simulations (Fig. 1) (allopatric treatment: $C$. antillensis: $\mathrm{G}=5.72^{\text {ns }} ;$ C. sclopetarius: $\mathrm{G}=1.12^{\text {ns; }}$; C. vittatus: $\mathrm{G}=1.58^{\text {ns; }}$; sympatric treatment: $C$. antillensis: $\mathrm{G}=5.58^{\text {ns }} ;$ C. sclopetarius: $\mathrm{G}=2.22^{\text {ns }}$; C. vittatus: $\mathrm{G}=1.94^{\text {ns }} ; \mathrm{df}=3$ for all comparisons). The substrate selection of $C$. antillensis, $C$. sclopetarius, and $C$. vittatus did not vary between the allopatric and sympatric treatments in the low tide simulation $\left(\mathrm{G}=4.42^{\mathrm{ns}}, \mathrm{G}=4.22^{\mathrm{ns}}\right.$ and $\mathrm{G}=5.32^{\text {ns; }} ; \mathrm{df}=3$, respectively) (Fig. 1).

The patterns of substrate selection differed among crab species in the allopatric treatment (low tide, $\mathrm{G}=25.16$, $\mathrm{df}=6, \mathrm{p}<0.001$ ) where there was a greater similarity between $C$. sclopetarius and $C$. vittatus $\left(\mathrm{G}=7.70^{\mathrm{ns}}, \mathrm{df}=3\right)$ than between C. antillensis and these two species $(\mathrm{G}=11.02$, $\mathrm{df}=3, \mathrm{p}<0.005$, and $\mathrm{G}=11.32$, $\mathrm{df}=3, \mathrm{p}<0.005$, respectively). Substrate selection did vary among hermit crab species in the sympatric treatment although the overall $G$ test failed to show it $\left(\mathrm{G}=10.24^{\mathrm{ns}}, \mathrm{df}=6\right)$. A higher similarity was recorded between $C$. sclopetarius and both $C$. antillensis and $C$. vittatus $\left(\mathrm{G}=1.64^{\mathrm{ns}}, \mathrm{df}=3\right.$ and $\mathrm{G}=7.44^{\mathrm{ns}}$, $\mathrm{df}=3$, respectively) than between the two latter species $(\mathrm{G}=10.60, \mathrm{df}=3, \mathrm{p}<0.005)$ after the pair wise comparisons. Substrate use in the field proved dependent on crab species $(G=144.12, d f=6$, $\mathrm{p}<0.001)$ with a higher similarity between $C$. sclopetarius and both $C$. antillensis and $C$. vittatus $\left(\mathrm{G}=0.92^{\mathrm{ns}}, \mathrm{df}=3\right.$ and $\mathrm{G}=5.40^{\mathrm{ns}}, \mathrm{df}=3$, respectively) than between the two latter species $(\mathrm{G}=16.54$, df $=3, p<0.005)$.

The results of the sympatric treatment (low tide) were compared with field data on substrate use by these hermit crab species as described by Turra et al. (2000) (Fig. 1).

The three hermit crab species selected substrates in different proportions than those used in the field (C. antillensis: $\mathrm{G}=121.12, \mathrm{df}=3, \mathrm{p}<$ $0.001 ;$ C. sclopetarius: $\mathrm{G}=46.66, \mathrm{df}=3, \mathrm{p}<$ $0.001 ;$ C. vittatus: $\mathrm{G}=13.08, \mathrm{df}=3, \mathrm{p}<0.005$ ), with $C$. vittatus showing the least difference between the two simulations.

\section{DISCUSSION}

The substrate selection of the three Clibanarius species at Pernambuco Islet was not influenced by the variation in tidal simulations.

At low tide, the hermit crabs became inactive and did not move from the substrates selected during the high tide simulation.

Crabs on the rocky substrate moved into holes and/or shady areas at simulated low tide. This behavior was also observed in the field during ebb tides for other hermit crab species (SnyderConn, 1980; Taylor, 1981; Gherardi \& Vannini, 1989).

Some individuals of $C$. vittatus and $C$. sclopetarius that selected muddy or sandy substrates buried themselves when exposed to the air.

Burrowing can be easily seen in the studied area and is described for hermit crabs as a behavioral response to avoid desiccation (Reese, 1969; Taylor, 1981) and low temperatures (Rebach, 1974). Such behavioral adaptations together with high tolerances against water loss (Young, 1978; Turra \& Denadai, 2001) are thought to be extremely important in making possible intertidal exploitation by hermit crabs.

Rittschof et al. (1995) demonstrated that hermit crabs have locomotory abilities to migrate with tides and avoid air exposure in the intertidal region. This is further evidence of the advantages hermit crabs have in occupying the intertidal environment, as pointed out by Reese (1969), despite the desiccation risks. 


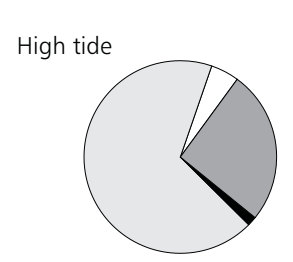

Low tide

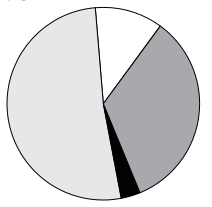

High tide

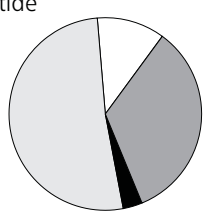

Low tide

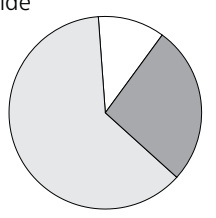

Low tide

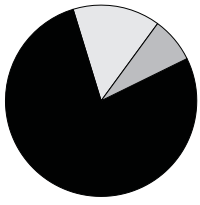

C. antillensis
Allopatric treatment
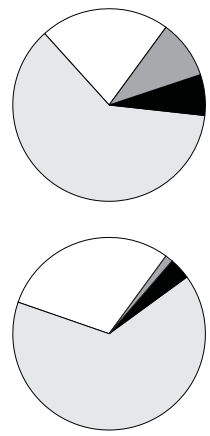

Sympatric treatment
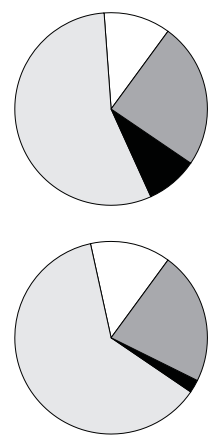

Field

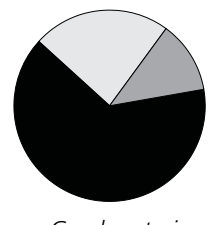

C. sclopetarius

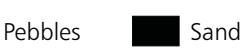

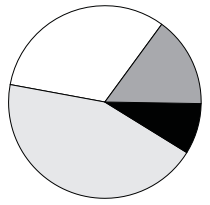
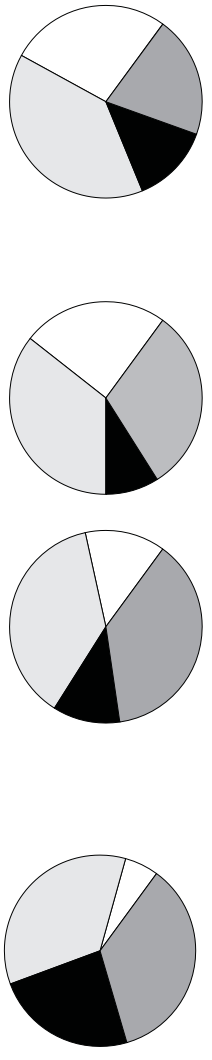

C. vittatus

Mud

Fig. 1 - Patterns of substrate use in nature and selection in allopatric (single species) and sympatric (three species) treatments in high tide and low tide simulations by the coexisting hermit crabs (Clibanarius antillensis, C. sclopetarius, and C. vittatus) in the intertidal region of Pernambuco Islet, Araçá region, São Sebastião Channel, southeastern Brazil. 
These hermit crab species did not use microhabitats randomly in the intertidal region of Pernambuco Islet (Turra et al., 2000), indicating that they actively selected the sites on which they were sampled. In fact, $C$. vittatus was the only species that used and selected substrates in similar ways. Clibanarius antillensis and $C$. sclopetarius selected substrates in different proportions than used in the field, i.e., they were sampled in suboptimal substrates. These results may indicate that, according to Bertness (1981), the presence of $C$. vittatus in the preferred substrate type (rock or pebbles) may displace the two other species to suboptimal areas in the field. This competitive effect would probably be higher for $C$. sclopetarius than for $C$. antillensis given the greater overlap in substrate selection between $C$. vittatus and the former species. In this way, the pattern of substrate use in nature may be explained by preferences only of $C$. vittatus.

A higher similarity in the patterns of substrate use and selection was verified between $C$. antillensis and $C$. sclopetarius in sympatric rather than in allopatric treatments. The presence of one species is supposed to increase the chances of other species to occur in a given substrate type. Clibanarius sclopetarius chose proportionally more pebbles in the sympatric treatment than in the allopatric one, where it selected mainly rocks. The presence of $C$. vittatus in its preferred substrate type, rocks, may be causing this shift by effectively excluding C. sclopetarius. In addition, the strong discrepancy between the use and selection of substrates by $C$. antillensis may be explained by its low desiccation tolerance (Turra \& Denadai, 2001) which limits this species strictly to sites near the water line where sand and mud predominate, and in sites with high environmental complexity (rocky shores with holes, crevices, or tide pools) (Turra et al., 2000).

Moreover, despite the sympatry of the three species of Clibanarius in the intertidal region of the studied area, they showed patchiness in their fine-grained distribution by microhabitat partitioning, and by different dispesion patterns and degrees of clustering behavior (Turra et al., 2000). This may reduce agonistic encounters and thus minimize competitive interactions (Gherardi, 1990; Gherardi \& Nardone, 1997). Such patterns may also emerge from substrate partitioning with the subordinate species occupying sub-optimal substrates, which may expose them to different shell supplies (Gherardi, 1990; Gherardi \& Nardone, 1997). In addition, differential preferences for substrates may be caused by microhabitat-related shell supplies (Mitchell, 1975). Microhabitat partitioning is also thought to be a behavioral response to shell fit (Gilchrist \& Abele, 1984; Rittschof et al., 1995) since crabs in less adequate shells display cryptic behavior more frequently than crabs in more adequate shells (Gilchrist \& Abele, 1984).

Acknowledgments - We would like to thank FAPESP (Proc. n. 97/00474-8) and CNPq (Proc. n. 133468/95-0) for scholarship grants to A. Turra and to FAEP (Proc. n. 0222/95) for grants to this research. Centro de Biologia Marinha of the Universidade de São Paulo (CEBIMar-USP) helped with technical and logistic support. Thanks to Dr. Fosca P. P. Leite for comments on the manuscript and for providing the background for the development of this research. Thanks to Giuliano B. Jacobucci, Arthur Z. Güth, and Arlindo Gomes Filho for valuable comments on the manuscript.

\section{REFERENCES}

BACH, C. B., HAZLETT, B. \& RITTSCHOF, D., 1976, Effects of interspecific competition on fitness of the hermit crab Clibanarius tricolor. Ecology, 57: 579-586.

BARNES, D. K. A., 1997, The ecology of tropical hermit crabs at Quirimba Island, Mozambique: distribution, abundance and activity. Mar. Ecol. Progr. Ser., 154: 133-142.

BERTNESS, M. D., 1981, Competitive dynamics of a tropical hermit crab assemblage. Ecology, 62(3): 751-761.

FOREST, J. \& SAINT LAURENT, M. de, 1967, Campagne de la Calypso au large des côtes Atlantiques de l'Amerique du Sud (1961-1962). 6. Crustacés - Décapodes: Pagurides. Annales de l'Institut Océanographique, 45(2): 47-169.

GHERARDI, F., 1990, Competition and coexistence in two Mediterranean hermit crabs Calcinus ornatus (Roux) and Clibanarius erythrops (Latreille) (Decapoda, Anomura). J. Exp. Mar. Biol. Ecol., 143: 221-238.

GHERARDI, F. \& NARDONE, F., 1997, The question of coexistence in hermit crabs: Population ecology of a tropical intertidal assemblage. Crustaceana, 70(5): 608-629.

GHERARDI, F. \& VANNINI, M., 1989, Field observations on activity and clustering in two intertidal hermit crabs, Clibanarius virescens and Calcinus laevimanus (Decapoda, Anomura). Mar. Behav. Physiol., 14: 145-159.

GHERARDI, F. \& VANNINI, M., 1992, Hermit crabs in a mangrove swamp: clustering dynamics of Clibanarius laevimanus. Mar. Behav. Physiol., 21: 85-104.

GHERARDI, F. \& VANNINI, M., 1993, Hermit crabs in a mangrove swamp: proximate and ultimate factors in the clustering of Clibanarius laevimanus. J. Exp. Mar. Biol. Ecol., 168: 167-187.

GILCHRIST, S. \& ABELE, L. G., 1984, Effect of sampling method on the estimation of population parameters in hermit crabs. J. Crust. Biol., 4: 645-654. 
IMAZU, M. \& ASAKURA, A., 1994, Distribution, reproduction and shell utilization patterns in three species of intertidal hermit crabs on a rocky shore on the Pacific coast of Japan. J. Exp. Mar. Biol. Ecol., 184: 41-65.

KELLOGG, C. W., 1977, Coexistence in a hermit crab species ensemble. Biol. Bull., 153: 133-144.

LEITE. F. P. P., TURRA, A. \& GANDOLFI, S. M., 1998, Hermit crabs, gastropod shells, and environmental structure: their relationship in southeastern Brazil. J. Nat. Hist., 32 (6): 1599-1608

LOWERY, W. A. \& NELSON, W. G., 1988, Population ecology of the hermit crab Clibanarius vittatus (Decapoda: Duogenidae) at Sebastian Inlet, Florida. J. Crust. Biol., 8(4): 548-556.

MELO, G. A. S., 1999, Manual de identificação dos Crustacea Decapoda do litoral brasileiro. Ed. Plêiade/FAPESP, São Paulo, 551p.

MITCHELL, K. A., 1975, An analysis of shell ocupation by two sympatric species of hermit crabs. I. Ecological factors. Biol. Bull., 149: 205-213.

REBACH, S., 1974, Burying behavior in relation to substrate and temperature in the hermit crab, Pagurus longicarpus. Ecology, 55: 195-198.

REESE, E. S., 1969, Behavioral adaptations of intertidal hermit crabs. Am. Zool., 9(2): 343-355.

RITTSCHOF, D., SARRICA, J. \& RUBEINSTEIN, D., 1995, Shell dynamics and microhabitat selection by striped legged hermit crabs, Clibanarius vittatus (Bosc). J. Exp. Mar. Biol. Ecol., 192: 157-172.

SCULLY, E. P., 1979, The effects of gastropod shell availability and habitat characteristics on shell utilization by the intertidal hermit crab Pagurus longicarpus Say. J. Exp. Mar. Biol. Ecol., 37: 139-152.
SNYDER-CONN, E. K., 1980, Tidal clustering and dispersal of the hermit crab Clibanarius digueti. Mar. Behav. Physiol., 7: 135-154.

SNYDER-CONN, E. K., 1981, The adaptative significance of clustering in the hermit crab Clibanarius digueti. Mar. Behav. Physiol., 8: 43-53.

TAYLOR, P. R., 1981, Hermit crab fitness: the effect of shel condition and behavioral adaptations on environmental resistance. J. Exp. Mar. Biol. Ecol., 52: 205-218.

TURRA, A. \& DENADAI, M. R., 2001, Desiccation tolerances of four tropical sympatric intertidal hermit crabs populations (Decapoda, Anomura). Mar. Fresh. Behav Physiol., 34: 227-238.

TURRA, A. \& LEITE, F. P. P., 2000, Clustering behavior of hermit crabs (Decapoda, Anomura) in an intertidal rocky shore at São Sebastião, southeastern Brazil. Rev. Brasil. Biol., 60: 39-44.

TURRA, A., JACOBUCCI, G. B., ARAÚJO, F. M. P. \& LEITE, F. P. P., 2000, Spatial distribution of four sympatric species of hermit crab (Decapoda, Anomura). In: J. C. von V. Klein and F. Schram (eds.), The biodiversity crisis and crustacea. A. A. Balkema, Rotterdam, pp. 261273.

VANCE, R. R., 1972, Competition and mechanisms of coexistence in three sympatric species of intertidal hermit crabs. Ecology, 53: 1062-1074.

YOUNG, A. M., 1978, Desiccation tolerances for three hermit crab species Clibanarius vittatus (Bosc), Pagurus pollicaris Say and $P$. longicarpus Say (Decapoda, Anomura) in the North Inlet Estuary, South Carolina, USA Est. Coast. Mar. Sci., 6: 117-122.

ZAR, J. H., 1996, Biostatistical analysis. Prentice-Hall, 718p. 